Chirurgia (2018) 113: 202-209

No. 2, March - April

Copyright $\odot$ Celsius

http://dx.doi.org/10.21614/chirurgia.113.2.202

\title{
Robotic Approach in Benign and Malignant Esophageal Tumors; A Preliminary Seven Case Series
}

\author{
Victor Tomulescu ${ }^{1,2}$, Codrut Stanescü2, Cristian Blajut ${ }^{2}$, Loredana Barbulescu², Gabriela Droc ${ }^{3}$, Vlad Herlea \\ Irinel Popescu
}

'Ponderas Academic Hospital, Bucharest, Romania

${ }^{2}$ Center for General Surgery and Liver Transplantation "Dan Setlacec", Fundeni Clinical Institute, Bucharest, Romania

${ }^{3}$ Centre of Anaesthesiology and Intensive Care, Fundeni Clinical Institute, Bucharest, Romania

${ }^{4}$ Department of Pathology, Fundeni Clinical Institute, Bucharest, Romania

Corresponding author:

Tomulescu Victor, MD

Ponderas Academic Hospital

Nicole Caramfil 85A, Bucharest, Romania

E-mail: victor.tomulescu@gmail.com
Received: 16.02 .2018

Accepted: 18.03 .2018

\section{Rezumat}

Abordul robotic al tumorilor esofagiene benigne și maligne; o serie preliminară de șapte cazuri

Chirurgia esofagiană are un grad ridicat de dificultate pentru chirurg şi cu multiple riscuri pentru pacienți. Chirurgia toracoscopică şi-a dovedit valoarea în abordarea patologiei esofagiene, dar prezinta câteva dezavantaje precum tremorul sau numărul limitat al gradelor de libertate, mişcări contraintuitive şi efectul de pivot al instrumentelor. Tehnologia robotică a fost dezvoltată pentru a surmonta aceste limitări. Beneficiile aduse de chirurgia robotică reprezintă avantaje deosebite mai ales în cazul intervențiilor chirurgicale care se desfăşoară în spații înguste cu acces dificil cum este cazul chirurgiei esofagiene.

Scop: Scopul acestui articol este de a prezenta experiența noastră redusă în abordul robotic al tumorilor esofagiene benigne sau maligne şi de a evalua în mod critic datele din literatura în legătură cu acest subiect

Metoda: In perioada Ianuarie 2008 - Septembrie 2016 abordul chirurgical robotic al tumorilor esofagiene benigne sau maligne a fost utilizat în Centrul de Chirurgie Generală şi Transplant Hepatic al Institutului Clinic Fundeni "Dan Setlacec" în şapte pacienți. Acesta a constat în disecția întregului esofag toracic ca parte a unui procedeu abdomino-toracic-cervical pentru cancer esofagian în trei pacienți, excizia unui leiomiom esofagian în trei cazuri şi a unui chist de incluziune esofagiană într-un caz. 
Rezultate: Toate intervențile au putut fi terminate prin abord robotic mai puțin un caz care a fost convertit la chirurgie clasică. Acesta a reprezentat primul caz de tumoră esofagiană abordată robotic - un leiomiom al esofagului inferior cu ulcerație a mucoasei supraiacente. Rezultatele histopatologice au confirmat leiomioamele esofagiene, chistul de incluziune esofagian şi cele trei cazuri de carcinoame scuamoase, cu marginile de rezecție libere de tumoră. Numărul mediu de ganglioni excizați a fost 24 $(22$-27). Evoluția postoperatorie a fost simplă în patru cazuri, în celelalte trei am întâlnit o fistulă esofagiană la pacientul convertit la chirurgie clasică (fistula s-a închis în ziua 14), un drenaj prelungit toracic la unu din pacienții cu esofagectomie şi o paralizie temporară de nerv recurent drept la un altul. La momentul redactării articolului unul din pacienții cu neoplasm esofagian şi toți cu leziuni benigne sunt în viață, asimptomatici şi fără semne de recurență.

Concluzii: Experiența nostră este limitată şi nu putem concluziona despre beneficiile la distanță ale chirurgiei robotice în abordarea tumorilor esofagiene. Rezultatele precoce au fost superioare chirurgiei deschise dar similare abordului clasic toracoscopic. Am observat avantaje certe ale chirurgiei robotice legate de limfadenectomie, disecția sigură a tumorilor benigne de mucoasa esofagiană şi sutură. Din punct de vedere al ergonomiei chirurgia robotică este mult superioară toracoscopiei.

Cuvinte cheie: chirurgie robotică, tumori esofagiene benigne, cancer esofag, leiomiom esofagian, chist de incluziune esofagian

\begin{abstract}
Esophageal surgery has been recognized as very challenging for surgeons and risky for patients. Thoracoscopic approach have proved its benefit in esophageal surgery but has some drawbacks as tremor and limited degrees of freedom, contra-intuitive movements and fulcrum effect of the surgical tools. Robotic technology has been developed with the intent to overcome these limitations of the standard laparoscopy or thoracoscopy. These benefits of robotic procedure are most advantageous when operating in remote areas difficult to reach as in esophageal surgery.

Aim: The aim of this paper is to present our small experience related with robotic approach in benign and malignant esophageal tumors and critically revise the evidence available about the use of the robotic technology for the treatment of these pathology.

Methods: From January 2008 to September 2016 robotic surgery interventions related with benign or malignant esophageal tumors were performed in "Dan Setlacec" Center for General Surgery and Liver Transplantation of Fundeni Clinical Institute in seven patients. This consisted of dissection of the entire esophagus as part of an abdomino-thoracic-cervical procedure for esophageal cancer in 3 patients and the extirpation of an esophageal leiomyoma in 3 cases and a foregut esophageal cyst in one case.

Results: All procedures except one were completed entirely using the da Vinci robotic system. The exception was the first case - a $3 \mathrm{~cm}$ leiomyoma of the inferior esophagus with ulceration of the superjacent esophageal mucosa. Pathology reports revealed three esophageal leiomyoma, one foregut cyst and three squamous cell carcinomas with free of tumor resection margins. The mean number of retrieved mediastinal nodes was $24(22-27)$. The postoperative course was uneventful in four cases, in the other three a esophageal fistula occurred in the converted leiomyoma case (closed in the 14th postoperative day), a prolonged drainage in one esophageal cancer case and a temporary right recurrent nerve palsy in an other one. One patient with esophageal cancer and all patients with benign lesions are alive with no signs of recurrence and no symptomatology.

Conclusion: Our experience is limited and we cannot conclude for the long term benefits of robotic surgery for esophageal tumors. In our experience the early outcomes were better then using classic open approach, but similar with the cases performed by thoracoscopic approach. We have noticed significant advantages of robotic surgery in relation of lymph node retrieval, leiomyoma dissection
\end{abstract}


safe from esophageal mucosa and suturing. Ergonomics for the surgeon was incomparable better then with the thoracoscopic approach.

Key words: robotic surgery, benign and malignant esophageal tumors, esophageal carcinoma, esophageal leiomyoma, esophageal inclusiom cyst

\section{Introduction}

Esophageal surgery has been recognized as very challenging for surgeons and risky for patients due to the potentially severe complications that can occur after conventional surgery. The deep location of the esophagus in the neck, the posterior mediastinum and the upper abdomen, very close to major vascular structures, the trachea and the pericardium, are important issues related with this potential difficult surgery. Reductions of postoperative complications, length of hospital stay, and pain and better cosmetic results are the benefits expected after minimally invasive surgery, benefits potentially of great interest when dealing with the esophageal surgery.

On the other hand, conventional laparoscopic or thoracoscopic surgery has some drawbacks as tremor and limited degrees of freedom, contraintuitive movements and fulcrum effect of the surgical tools. The need for a human assistant to hold and move the camera makes surgeons lose the independent ability of controlling the operation field (1). Robotic technology has been developed with the intent to overcome these limitations of the standard laparoscopy. It offers several potential technical improvements, such as the three-dimensional visualization of the operating field with a quality at a level not accomplished by laparoscopic cameras and with a stable camera that is manipulated by the surgeon, increased movement accuracy and precision secondary to the enhanced maneuverability of 7 degrees of freedom instruments, and better surgeon ergonomics (2). These benefits of robotic procedure are most advantageous when operating in remote areas difficult to reach, whereas procedures requiring frequent instrument changes in an open operating field are less suitable (3).

\section{Aim}

The aim of this paper is to present our small experience related with robotic approach in benign and malignant esophageal tumors and critically revise the evidence available about the use of the robotic technology for the treatment of these pathology.

\section{Methods}

From January 2008 to September 2016 minimally invasive approach interventions related with benign or malignant esophageal tumors were performed in "Dan Setlacec" Center for General Surgery and Liver Transplantation of Fundeni Clinical Institute with the da Vinci S and then SI robotic system in 7 patients. Al patients have been extensively evaluated with CT scan, endoscopy and endoscopic ultrasonography. No preoperative radio chemotherapy was decided by the tumor board for the oncologic patients due to early stages. Our local ethics committee approved robotic approach and informed consent was obtained from all patients. The robotic assisted thoracoscopic approach consisted in dissection of the entire esophagus as part of an abdominothoracic-cervical procedure for esophageal cancer in three patients and the extirpation of an esophageal leiomyoma in three cases and a foregut esophageal cyst in one case.

The patient characteristics are given in Table 1. 
Table 1.

\begin{tabular}{|c|c|c|c|c|c|c|c|c|c|}
\hline $\mathrm{Nr}$ & & $\begin{array}{l}\text { Associate } \\
\text { disorders }\end{array}$ & Approach & $\begin{array}{l}\text { Set-up time/ } \\
\text { Console time } \\
\quad \text { (min) }\end{array}$ & $\begin{array}{l}\text { Ov Op } \\
\text { Time } \\
(\min )\end{array}$ & Complications & $\begin{array}{l}\text { Po } \\
\text { stay }\end{array}$ & Histology & Evolution \\
\hline 1 & $\begin{array}{l}38 y \\
\text { man }\end{array}$ & & $\begin{array}{l}\text { Robotic laparoscopic myotomy } \\
\text { with tumor enucleation }\end{array}$ & $20 / 180$ & 240 & $\begin{array}{l}\text { Esophageal } \\
\text { fistulae }\end{array}$ & 21 & $\begin{array}{l}\text { Esophageal leiomyoma } \\
\text { of inf esophagus }\end{array}$ & $\begin{array}{l}\text { Normal transit } \\
\text { and EGD at } 1 \text {, } \\
2,3 \text { y control }\end{array}$ \\
\hline 2 & $\begin{array}{l}57 \mathrm{y} \\
\text { man }\end{array}$ & $\begin{array}{l}\text { Chronic } \\
\text { Hepatitis } \\
\text { (HBV) }\end{array}$ & $\begin{array}{l}\text { Robotic thoracoscopic } \\
\text { and abdominal laparoscopic } \\
\text { esophagectomy with cervical } \\
\text { anastomosis }\end{array}$ & $45 / 180$ & 260 & no & 11 & $\begin{array}{l}\text { T1N0M0 } \\
\text { Epidermoid carcinoma } \\
\text { of md esophagus } \\
25 \text { lymph nodes } \\
\text { no metastases }\end{array}$ & $\begin{array}{l}50 \text { month po } \\
\text { No sign of } \\
\text { recurrence }\end{array}$ \\
\hline 3 & $\begin{array}{c}50 \mathrm{y} \\
\text { women }\end{array}$ & $\begin{array}{l}\text { Cvadruple } \\
\text { aorto-coronary } \\
\text { bypass } \\
\text { Bimodal } \\
\text { psichiatric disorder }\end{array}$ & $\begin{array}{l}\text { Robotic thoracoscopic } \\
\text { and abdominal } \\
\text { esophagectomy with } \\
\text { cervical anastomosis }\end{array}$ & $40 \mathrm{~min} / 220$ & 300 & $\begin{array}{l}\text { Prolonged } \\
\text { bilaterally } \\
\text { drainage }\end{array}$ & 15 & $\begin{array}{l}\text { T2 N1 M0 } \\
\text { Epidermoid carcinoma } \\
\text { of md esophagus } \\
27 \text { lymph nodes } \\
4 \text { metastases }\end{array}$ & $\begin{array}{l}\text { Death } 18 \\
\text { month po } \\
\text { Suicide } \\
\text { No sign of } \\
\text { recurrence }\end{array}$ \\
\hline 4 & $\begin{array}{l}63 y \\
\text { men }\end{array}$ & Diabetus & $\begin{array}{l}\text { Robotic thoracoscopic } \\
\text { and abdominal laparoscopic } \\
\text { esophagectomy with cervical } \\
\text { anastomosis }\end{array}$ & $30 / 150$ & 240 & $\begin{array}{l}\text { Temporary right } \\
\text { recurrent nerve } \\
\text { palsy }\end{array}$ & 10 & $\begin{array}{l}\text { T2 N2M0 } \\
\text { Squamos carcinoma } \\
\text { of upper third of } \\
\text { esophagus } 22 \text { lymph } \\
\text { nodes } 8 \text { with metastases } \\
\text { ( } 2 \text { in abdominal area) }\end{array}$ & $\begin{array}{l}\text { One year } \\
\text { multiple } \\
\text { pulmonary } \\
\text { metastases }\end{array}$ \\
\hline 5 & $\begin{array}{c}56 \mathrm{y} \\
\text { women }\end{array}$ & Arterial hypertension & $\begin{array}{l}\text { Robotic thoracoscopic } \\
\text { myotomy with tumor } \\
\text { enucleation }\end{array}$ & $30 / 150$ & 240 & no & 6 & $\begin{array}{l}\text { Esophageal leiomyoma } \\
\text { of md esophagus }\end{array}$ & $\begin{array}{l}\text { Normal transit } \\
\text { and EGD at } 1 \text {, } \\
2,3 \text { y control }\end{array}$ \\
\hline 6 & $\begin{array}{l}38 y \\
\operatorname{man}\end{array}$ & & $\begin{array}{l}\text { Robotic thoracoscopic } \\
\text { myotomy with tumor } \\
\text { enucleation }\end{array}$ & $15 / 120$ & 120 & no & 5 & $\begin{array}{l}\text { Esophageal leiomyoma } \\
\text { of md esophagus }\end{array}$ & $\begin{array}{l}\text { Normal transit } \\
\text { and EGD at } 1 \text {, } \\
2,3 \text { y control }\end{array}$ \\
\hline 7 & $\begin{array}{l}42 \mathrm{y} \\
\operatorname{man}\end{array}$ & Diabetus & $\begin{array}{l}\text { Robotic thoracoscopic myotomy } \\
\text { with tumor enucleation }\end{array}$ & $15 / 120$ & 150 & no & 5 & $\begin{array}{l}\text { esophageal inclusion } \\
\text { cyst }\end{array}$ & $\begin{array}{l}\text { Normal transit } \\
\text { and EGD at } 1 \text {, } \\
2,3 \text { y control }\end{array}$ \\
\hline
\end{tabular}

\section{Operative Tehniques}

The first case was a $3 \mathrm{~cm}$ leiomyoma of the inferior esophagus with ulceration of the superjacent esophageal mucosa and bleeding, approached by abdominal route. The trocar position was similar to robotic eso-cardiomyotomy approach. We were using four arms, controlling one instrument for retraction (placed in right hipochondryum), the camera port at $2 \mathrm{~cm}$ left laterally at the union $2 / 3$ to $1 / 3$ of the xifo-umbilical line, 2 working instrument ports $8 \mathrm{~cm}$ right and left laterally to the camera port and one $12 \mathrm{~mm}$ port for the assistant in the left hipochondryum. The left crura approach is used routinely and the short gastric vessels are divided carefully. Then we dissect the right crura and dissection is continued in the posterior mediastinum laterally and anteriorly to expose the lower third of the esophagus. After, we have dissected completely the esophagus and place a Penrose drain around it, we continue the dissection of the lower esophagus in order to abdominalize more the esophagus. Cadiere forceps and robotic scissors were used interchangeably between left or right arms during dissection. A four centimeters myotomy was performed and the tumor was dissected from the esophageal mucosa using the scissor. During the dissection of the tumor a lesion of the esophageal mucosa was seen at the level of the ulceration evaluated previous endoscopic. Excision of the tumor in healthy tissue had left a large esophageal mucosa defect. Being the first robotic case we have decided to convert the case and to perform the esophageal suture and a Dor fundoplication by open approach. A feeding jejunostomy has been placed too.

In the robotic thoracoscopic approach all procedures were performed from the right with the patient in complete left lateral decubitus position with selective left lung ventilation. The robotic cart was situated at the right side of the patient. 
The trocars for the robot (one 10-mm trocar for the camera and two 8-mm trocars for the arms) were placed - camera trocar in the sixth intercostal space in the posterior-axillary line, left robotic arm in the eighth intercostal space in the posterior-axillary line, right robotic arm in the forth intercostal space in the midaxillary line and the auxiliary port for suction retraction or stapling in the eighth intercostal space in the anterior-axillary line appropriate with the recommendations of Dutch group $(4,5)$. We have used CO2 insufflation up to $10 \mathrm{~mm} \mathrm{Hg}$ similar we are using in other robotic or classic thoracoscopic approach procedures [thymectomies for example (6)], insufflation that allows us to a better exploration of the pleural cavity (7) and help us in the dissection of the esophagus. It is similar with a pneumomediastinum and enables a better lymphadenectomy. Cadiere forceps or fenestrated bipolar forceps and robotic scissors were used interchangeably between left or right arms during dissection. Robotic system transforms a right dominant arm surgeon in an ambidextrous one.

Robot assisted thoraco-laparoscopic esophagectomy with two field lymphadenectomy was performed for the patients with epidermoid carcinoma of mid or upper thoracic esophagus. The procedure began with the incision of the mediastinal pleura between the esophagus and the lung just inferior to the azygos vein and then superior to it (Fig. 1). Division of the azygos vein was performed either using a vascular endostapler or with suture ligation and clipping (Fig 2). In one case the azygos vein was preserved. The caudal limit of the dissection was the hiatus. The thoracic duct was identified and clipped in all cases (Fig. 3). The plane of dissection was outside the vagus. Circumferential mobilization of the esophagus, including surrounding lymph nodes and per-esophageal tissue (Fig. 4), was performed from the diaphragmatic reflection to the thoracic inlet, the posterior large direct aortic arterial esophageal branches being clipped, and the small branches cauterized with bipolar forceps. The bipolar robotic forceps is very efficient and the clips have been used rare. A Penrose drain that surrounds the esophagus,

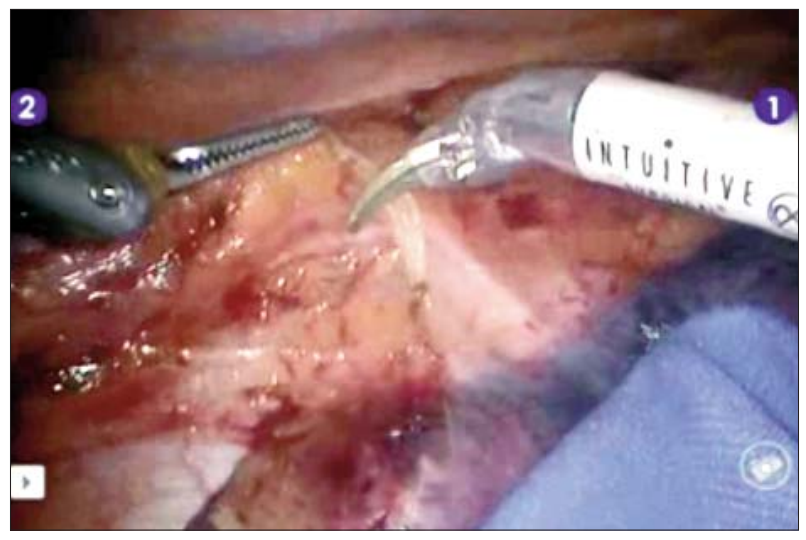

Figure 1. Beginning the esophageal dissection

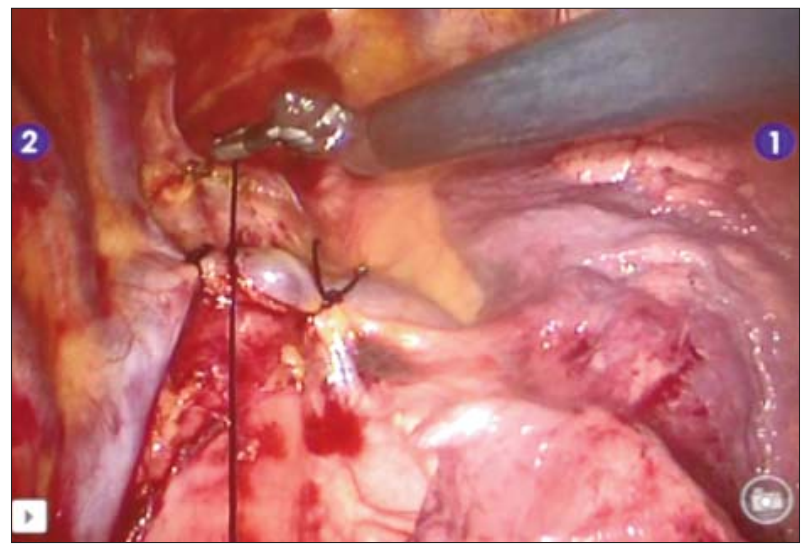

Figure 2. Suture-ligation of the azygos vein

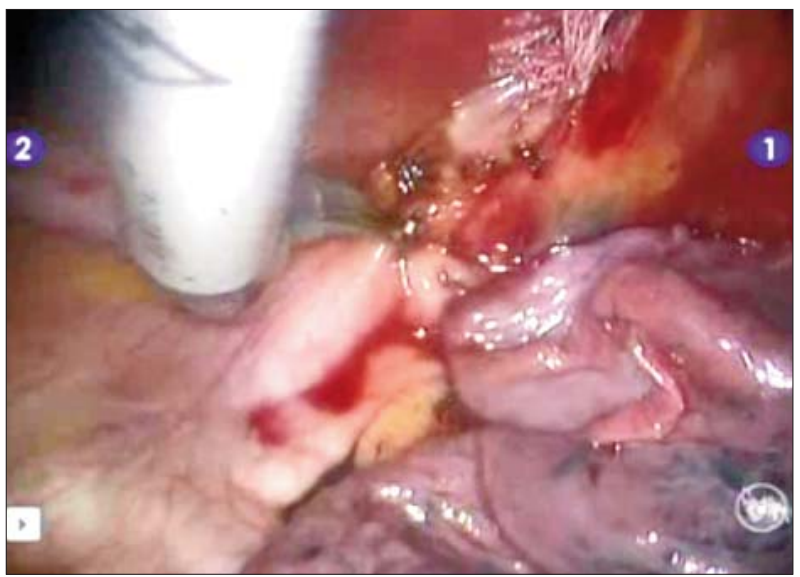

Figure 3. Sectioning the thoracic duct after clipping

permit mobilization of the esophagus and enables a superior thoracic lymphadenectomy. That included the right and left paratracheal lymph nodes), tracheobronchial lymph nodes, paraaortic nodes subcarinal nodes peri- 


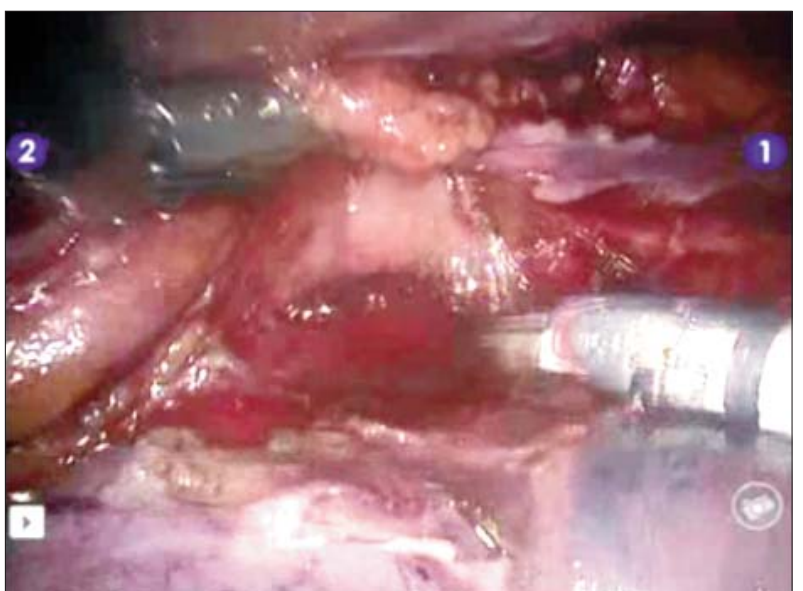

Figure 4. Circumferential mobilization of the esophagus, including surrounding lymph nodes and per-esophageal tissue

esophageal nodes and pulmonary ligament nodes. A drainage tube was inserted and hereafter the patient was positioned in supine position to facilitate laparoscopic gastric mobilization and abdominal lymphadenectomy (right and left cardiac lymph nodes, left gastric artery nodes, celiac artery nodes, infra-diaphragmatic nodes and lymph nodes in the esophageal hiatus of the diaphragm). The stomach was mobilized on the right gastro epiploic and right gastric artery. The stomach tube was prepared extra-corporeally by making $5 \mathrm{~cm}$ incision in the midline, the specimen being extracted through with the help of a wound protector.

The $3^{-}$to $4^{-\mathrm{cm}}$-wide gastric tube was fashioned with GIA staplers, and the stapled line was oversewn with PDS 3/0. The stomach tube was attached to the NG tube and was pulled to the neck with caution to maintain orientation of the conduit, to prevent twisting or spiraling and then a hand sewn esophageogastric anastomoses was done. After the gastric tube had been pulled to the neck, a feeding jejunostomy was placed using the same incision laparoscopic assisted.

For the esophageal leiomyoma of mid esophagus robotic cart positioning and trocars placement were identical to the esophageal dissection procedure. In both cases the tumor was deep to the azygos vein and the parietal pleura have to incised to expose the esophagus

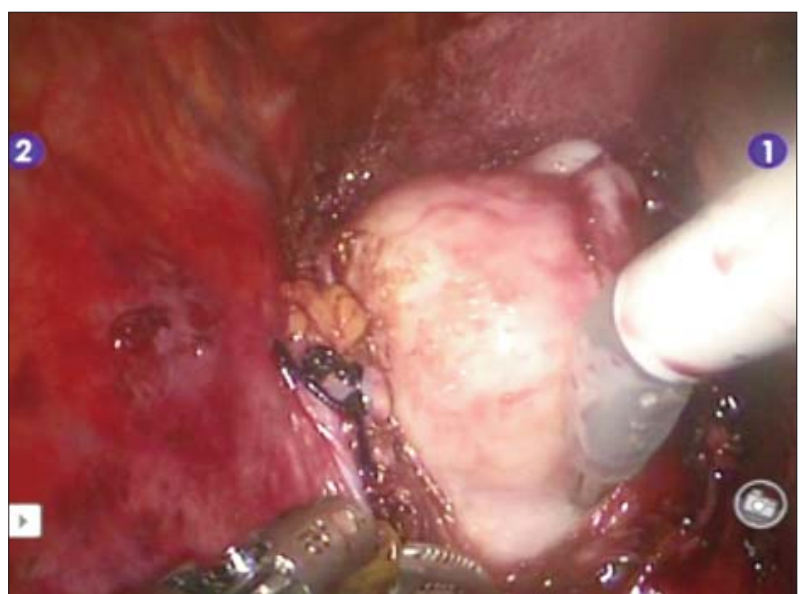

Figure 5. Leiomyoma dissection from the mucosa using the scissor

after the division of the azygos vein using a vascular endostapler in one case and after suture-ligation of it in the other case.

A 270 degree mobilization of the esophagus was needed in the first case because the tumor was $5 \mathrm{~cm}$ large and posterior situated, so a $7 \mathrm{~cm}$ myotomy was needed. The tumor was dissected from the mucosa using the scissor (Fig. 5). The integrity of the mucosa was confirmed by simultaneous upper endoscopy and bubble test. The tumor was removed in an endobag and the myotomy was closed using single sutures (Fig. 6). Due to a thoracic duct lesion clipping and suturing this on both sides of the esophagus was necessary. The second

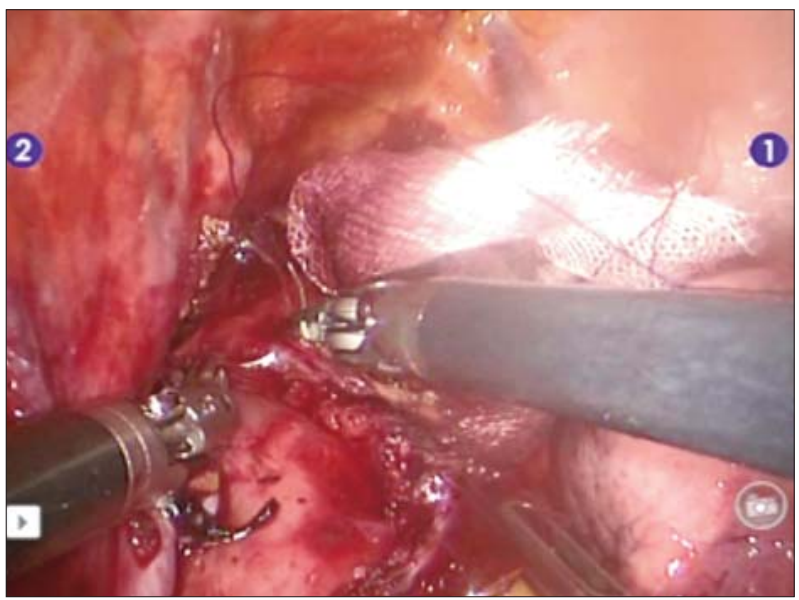

Figure 6. The myotomy was closed using single sutures 
case was a $3 \mathrm{~cm}$ leiomyoma easier to be dissected after suture-ligation and section of the azygos vein.

The esophageal inclusion cyst was located in the lower esophagus.

After division of the right pulmonary ligament the cyst was separated from adjacent muscular tissue, enucleated, and finally removed in an endobag, the esophageal muscular layer being repaired in a single stitch fashion. Endoscopic evaluation confirmed integrity of the mucosa.

\section{Results}

All procedures except one were completed entirely using the da Vinci robotic system. The exception was the first case - a $3 \mathrm{~cm}$ leiomyoma of the inferior esophagus with ulceration of the superjacent esophageal mucosa. The set-up time and total operative time are presented in Table 1. The intraoperative blood loss was minimal and we have not experienced any technical failure.

Pathology reports revealed three esophageal leiomyoma, one foregut cyst and three squamous cell carcinomas with free of tumor resection margins. The mean number of retrieved mediastinal nodes was $24(22-27)$.

The staging of the three squamous cell carcinoma cases and the clinical evolutions are depicted in Table 1. The postoperative course was uneventful in four cases, in the other three a esophageal fistula occurred in the converted leiomyoma case (closed in the $14^{\text {th }}$ postoperative day), a prolonged bilateral pleural drainage in one esophageal cancer case and a temporary right recurrent nerve palsy in an other one.

One patient with esophageal cancer and all patients with benign lesions are alive with no signs of recurrence and no symptomatology. The deaths were related with pulmonary metastases 16 month after resection in one case and suicide in 14 month the other.

\section{Discussion}

Our series is a small one in relation with other centers but it represents the first experience with robotic approach in benign and malignant esophageal tumors in our country. Esophagectomy using a conventional minimally invasive approach is an advanced surgical procedure with a long learning curve. We have performed this technique for the first time in the year 2000 by thoracoscopic approach with good results (8). The classic thoracoscopic step of the esophagectomy is really uncomfortable due to the 2D planar vision, the fulcrum effect through the thoracic wall and the use of nonarticulated instruments(9). Robotic surgery comes with improved $3 \mathrm{D}$ vision that offers the surgeons the impression that he is inside the patient and the camera platform is stable. The dexterity and articulated instruments permit seven degrees of motion including in/out; rotation; pitch at wrist; yaw at wrist; pitch at fulcrum; yaw at fulcrum and grip strength (10). Tremor elimination, ambidextrous capability, motion scaling and excellent ergonomics simulates the fluid movements of a surgeon's wrist helping to overcome the limited mobility imposed by rigid thoracic cavity.

$87 \%$ of surgeons who perform minimally invasive surgery report experiencing some kind of pain related to performing minimally invasive procedures by classic approach (11), thoracoscopic esophagectomy being a long and difficult position for the surgeon procedure. With robotic approach surgeon performs this long complex procedure while sitting in a comfortable and ergonomic position and this is in the benefit of the patient also.

We consider that the stable 3-dimensional view of the surgical field along with articulated surgical tools might help reach the upper mediastinum with better ergonomics, and allow a wide and precise dissection of the esophagus and periesophageal tissues and the mediastinal structures thus leading, as the Dutch group have speculated, to a higher number of lymph node harvested and possibly to higher rates of radicality in patients with large tumor providing good local control with a low percentage of local recurrence at long-term follow up $(4,12)$. Dissection of a large esophageal leiomyoma from the subjacent mucosa is easier and safer performed using the 
robotic approach, suturing and dexterity skills are performed quicker than does manual thoracoscopy or laparoscopy (13). These cases have to be very well investigated and the patients in early stage of the disease. Unfortunately in our country most of the patients with esophageal cancer approach the medical system in advanced stages and is difficult to offer in those cases a minimal invasive approach.

Our experience is limited and we cannot conclude for the long term benefits of robotic surgery for esophageal tumors. It is clear that results from large RCTs with long-term outcomes like the ongoing ROBOT trial (14) are needed to validate the robotic approach for the surgical treatment of esophageal cancer.

Integration of the robotic system with indocyanine green (ICG) fluorescein imaging system (Firefly system) for to evaluate the gastric conduit blood supply during reconstructive part of esophageal cancer surgery (15) and with advanced diagnostic imaging system like CT scans are actual and potential future developments that will add important benefits for the patient in relation with robotic surgery opening the way to integration of planning, diagnostics and therapy.

\section{Conclusion}

In our experience the early outcomes were better then using classic open approach, but similar with the cases performed by thoracoscopic approach.

We have noticed significant advantages of robotic surgery in relation of lymph node retrieval, leiomyoma dissection safe from esophageal mucosa and suturing. Ergonomics for the surgeon was incomparable better then with the thoracoscopic approach.

\section{Conflicts of Interest}

The authors have no conflicts of interest to declare.

\section{References}

1. Vasilescu C, Popescu I. Robotic surgery--possibilities and perspectives. Chirurgia (Bucur). 2008;103(1):9-11. Romanian

2. Bencini L, Moraldi L, Bartolini I, Coratti A. Esophageal surgery in minimally invasive era. World J Gastrointest Surg. 2016;8(1):5264. doi: 10.4240/wjgs.v8.i1.52.

3. Bodner JC, Zitt M, Ott H, Wetscher GJ, Wykypiel H, Lucciarini P, et al. Robotic-assisted thoracoscopic surgery (RATS) for benign and malignant esophageal tumors. The Annals of thoracic surgery. 2005;80(4):1202-6.

4. van der Sluis PC, Ruurda JP, Verhage RJ, van der Horst S, Haverkamp L, Siersema PD, et al. Oncologic Long-Term Results of Robot-Assisted Minimally Invasive Thoraco-Laparoscopic Esophagectomy with Two-Field Lymphadenectomy for Esophageal Cancer. Ann Surg Oncol. 2015;22 Suppl 3:S1350-6. doi: 10.1245/ s10434-015-4544-x. Epub 2015 May 29.

5. van Hillegersberg R, Boone J, Draaisma WA, Broeders IA, Giezeman $\mathrm{MJ}$, Borel Rinkes $\mathrm{IH}$. First experience with robot-assisted thoracoscopic esophagolymphadenectomy for esophageal cancer. Surg Endosc. 2006;20(9):1435-9. Epub 2006 May 15.

6. Tomulescu V, Sgarbura 0, Stanescu C, Valciu C, Campeanu A, Herlea $V$, et al. Ten-year results of thoracoscopic unilateral extended thymectomy performed in nonthymomatous myasthenia gravis. Annals of surgery. 2011;254(5):761-5; discussion 5-6.

7. Tomulescu V, Popescu I. Unilateral extended thoracoscopic thymectomy for nontumoral myasthenia gravis--a new standard. Semin Thorac Cardiovasc Surg. 2012 Summer;24(2):115-22. doi: 10.1053/ j.semtcvs.2012.06.003.

8. Tomulescu V, Stanciulea O, Balescu I, Vasile S, Tudor S, Gheorghe C, et al. First year experience of robotic-assisted laparoscopic surgery with 153 cases in a general surgery department: indications, technique and results. Chirurgia (Bucur). 2009;104(2):141-50.

9. Taurchini M, Cuttitta A. Minimally invasive and robotic esophagectomy: state of the art. Journal of visualized surgery. 2017;3:125.

10. Watson TJ. Robotic esophagectomy: is it an advance and what is the future? The Annals of thoracic surgery. 2008;85(2):S757-9.

11. Miller K, Benden M, Pickens A, Shipp E, Zheng Q. Ergonomics principles associated with laparoscopic surgeon injury/illness. Human factors. 2012;54(6):1087-92. PubMed PMID: 23397816.

12. Rebecchi F, Allaix ME, Morino M. Robotic technological aids in esophageal surgery. Journal of visualized surgery. 2017;3:7.

13. Yohannes $P$, Rotariu $P$, Pinto $P$, Smith $A D$, Lee $B R$. Comparison of robotic versus laparoscopic skills: is there a difference in the learning curve? Urology. 2002;60(1):39-45.

14. van der Sluis PC, Ruurda JP, van der Horst S, Verhage RJ, Besselink MG, Prins MJ, et al. Robot-assisted minimally invasive thoraco-laparoscopic esophagectomy versus open transthoracic esophagectomy for resectable esophageal cancer, a randomized controlled trial (ROBOT trial). Trials. 2012;13:230. doi: 10.1186/ 1745-6215-13-230.

15. Ohi M, Toiyama Y, Mohri Y, Saigusa S, Ichikawa T, Shimura T, et al. Prevalence of anastomotic leak and the impact of indocyanine green fluorescein imaging for evaluating blood flow in the gastric conduit following esophageal cancer surgery. Esophagus. 2017;14(4):351-9. doi: 10.1007/s10388-017-0585-5. Epub 2017 Jun 28. 